\title{
Wernicke-sjúkdómur meðal áfengissjúkra
}

\section{Björn Logi \\ Pórarinsson ${ }^{1}$}

almennur læknir

Elías Ólafsson ${ }^{1}$

taugalæknir

Ólafur

Kjartansson ${ }^{2}$

röntgenlæknir

Hannes

Blöndal ${ }^{3}$

taugameinalæknir,

prófessor emeritus

Lykilorð: Wernicke-sjúkdómur, Korsakoff-minnistruflun, píamín, píamínskortur, magnesíumskortur, vannæring, áfengissýki.

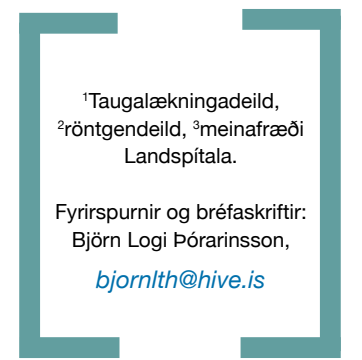

\section{Ágrip}

Wernicke-sjúkdómur hlýst af skorti á píamíni (B1 vítamíni) og er algengastur hjá einstaklingum með langvinna áfengissýki og vannæringu. Algengustu einkenni eru breytingar á hugarástandi, truflun á augnhreyfingum og stöðu- og göngulagstruflun. Sjúkdómurinn virðist mjög vangreindur en töf á réttri meðferð getur leitt til dauða eða Korsakoff-minnistruflunar. Einstaklingum með líklegan Wernicke skal tafarlaust gefið píamín í stórum skömmtum. Ekki skal bíða staðfestingar á greiningu áður en meðferð er hafin. Magnesíumskort ætti að leiðrétta samhliða. Áfengissjúkum einstaklingum sem eru í hættu á að fá sjúkdóminn skal ávallt gefa fyrirbyggjandi meðferð píamíns í vöðva eða æð við innlögn á sjúkrahús.

\section{Inngangur}

Wernicke-sjúkdómur (Wernicke'sencephalopathy) stafar af skorti á píamíni (B1-vítamín). Sjúkdómurinn sést við næringarskort af ýmsum ástæðum og er algengastur hjá einstaklingum með langvinna áfengissýki. Hann er vangreindur, helstu einkenni eru bráð og hann getur valdið varanlegum minnistruflunum eða dauða ef fullnægjandi meðferð er ekki beitt tímanlega. Píamínskortur getur einnig valdið hrörnun á hnykli (cerebellum) og úttaugameini (peripheral neuropathy). ${ }^{1}$

Wernicke var fyrst lýst árið 1881 af pýska lækninum Carl Wernicke (1848-1905), sem bráðum veikindum tveggja áfengissjúkra karlmanna og ungrar konu með langvarandi uppköst eftir að hafa drukkið brennisteinssýru í peim tilgangi að stytta sér aldur. Einkennin voru brátt ruglástand, skert meðvitund, augnvöðvalömun, augnatin (nystagmus) og óstöðugt göngulag. Sjúklingarnir dóu eftir skammvinn veikindi. Við krufningu sáust punktblæðingar umhverfis priðja og fjórða heilahólf ásamt smugu (aqueductus mesencephali). Wernicke nefndi sjúkdóminn „acute superior hemorrhagic polioencephalitis“.2, 3 Á árunum 1887-1889 lýsti rússneski læknirinn Sergei S. Korsakoff (1853-1900) svipuðum sjúkdómi í stærri hópi sjúklinga með brátt ruglástand og úttaugamein. Peir sem lifðu af fengu langvarandi truflun á skammtímaminni og varð illmögulegt að leggja nýja atburði á minnið. Sjúkdóminn nefndi hann ",polyneuritic psycosis“. ${ }^{4}$ Á fyrri hluta 20. aldar varð almennt viðurkennt að píamínskortur orsakaði bráðan Wernicke og að Korsakoff-minnistruflun (Korsakoff amnestic syndrome) væri langvinnur skaði af hans völdum. Allur sjúkdómsferillinn kallast Wernicke-Korsakoffheilkenni, komi einkenni Korsakoff fram eftir bráð veikindi Wernicke. ${ }^{1}$

\section{Faraldsfræði}

Upplýsingar um tíðni Wernicke byggjast einkum á krufningum. Lífsalgengi (lifetime prevalence) hans á Vesturlöndum er líklegast í kringum $1,0 \%$ (0,4-2,8\% í mismunandi rannsóknum). ${ }^{1,5-9}$ Oftast er skýr saga um vannæringu og 77-90\% sjúklinganna hafa lengi verið með áfengissýki. ${ }^{6,}{ }^{10}$ Við heilakrufningu hafa merki um Wernicke fundist hjá 8,9-12,5\% einstaklinga með langvinna áfengissýki. ${ }^{5,} 11$ Sjúkdómurinn sést einnig við vannæringu óháð áfengissýki, svo sem langvarandi svelti, ${ }^{12}$ mikil uppköst á meðgöngu ${ }^{13,14}$ og í kjölfar megrunarskurðaðgerða eða annarra aðgerða á meltingarvegi. ${ }^{15}$ Gjöf glúkósa ${ }^{16}$ eða langvarandi næringargjöf í æð ${ }^{17}$ án fullnægjandi píamíngjafar getur einnig valdið Wernicke. Hann hefur greinst hjá sjúklingum í blóð- og kviðskilun, ${ }^{18,19}$ hjá sjúklingum með ýmis krabbamein eða eftir beinmergsskipti ${ }^{20-22}$ og á meðal alnæmissjúkra. ${ }^{23,24}$

\section{Meinalífeðlisfræði}

Píamín er vatnsleysanlegt vítamín, frásogast í smágirni og finnst í margs konar fæðu. Dagspörf fullorðinna er um $1 \mathrm{mg}$ og heildarbirgðir líkamans eru 25-30 mg. Alvarlegur skortur verður á premur vikum ef neysla píamíns stöðvast. ${ }^{25}$ Píamíntvífosfat (TDP) er hið virka form píamíns innan frumna og er pað nauðsynlegur hjálparpáttur (cofactor) transketólasa (TK), pýrúvat dehýdrógenasa (PDH) og $\alpha$-ketóglútarat 

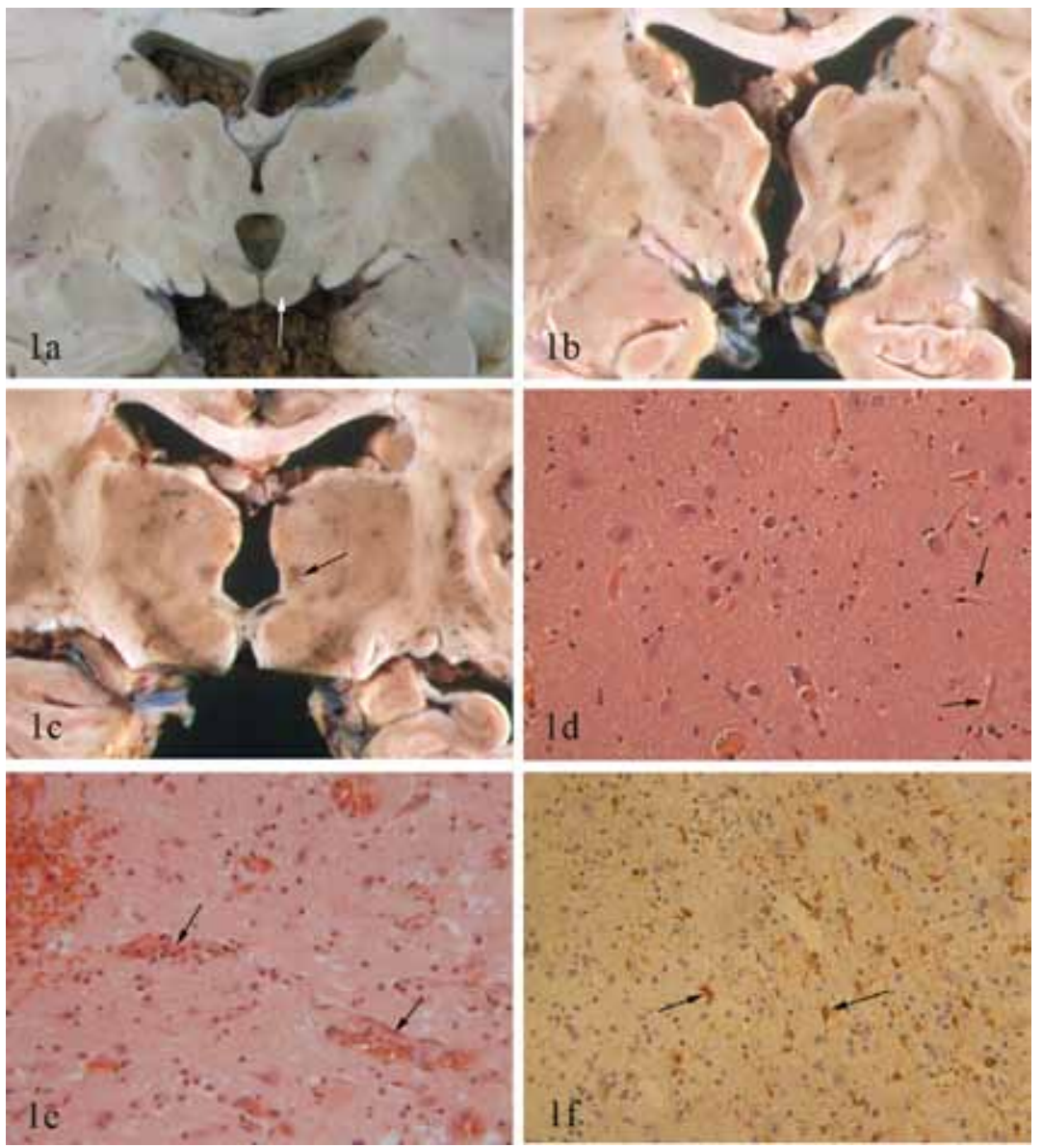

Mynd 1. Eðlilegir vörtukjarnar (ör) (1a). Vörtukjarnar í Wernicke. Smáblæðingar (dökkir blettir) og upplausn í vefnum (1b). Smáblæðingar jafnhliða i undirstúku (sjá ör) i sama sjúklingi (1c). Eđlilegur vörtukjarni (ljóssmásjá, hematoxylín-eosin, HE). Örvar benda á háræðar (1d). Vörtukjarni i Wernicke (sama tilfelli og 1b og 1c) með ferskri smáblæðingu, óeðlilegum háræðum (örvar) og losung (bjúgur) í taugaló (HE, 1e). Vefjaónæmislitun gegn stjarnfrumum (glial fibrillary acidic protein) litar stjarnfrumuviðbrögð brún (örvar) (1f)

*Pegar píamín er flutt inn i frumur líkamans myndast TDP fyrir tilstilli píamín pýrófosfókínasa. Magnesíum er nauðsynlegur hjálparpáttur ensímsins og virkni pess tengist styrk magnesiums. Auk pess parf bæði TDP og magnesíum til að mynda starfhæf heildarensím (holoenzyme) TK, PDH og a-KGDH, pví pau eru öll samsett úr ensímkjörnum (apoenzyme) sínum ásamt TDP og magnesíum. Magnesíumskortur getur valdið minnkaðri bindingu TDP við ensímkjarnana og dregið úr virkni ensímanna. Pess má geta að̃ aukinn styrkur magnesíum dregur úr NMDAviðtaka miðluðum frumudauða í dýratilraunum og mikill skortur eykur hann dehýdrógenasa ( $\alpha-\mathrm{KGDH})$ sem eru lykilensím í glúkósa- og amínósýruefnaskiptum líkamans. Píamínpörfin eykst við aukinn hraða efnaskipta, til dæmis við sýkingar. ${ }^{25}$

Hjá áfengissjúkum er lægra hlutfall píamíns á virku formi (TDP) og minni aukning TDP verður við píamíngjöf. Pví purfa áfengissjúkir stærri skammt af píamíni en aðrir til pess að sýna sömu svörun við gjöf pess. ${ }^{26}$ Auk pess er magnesíum nauðsynlegur hjálparpáttur við myndun TDP og magnesíumskortur, sem er algengur hjá áfengissjúkum, virðist auka skaða á taugakerfi við píamínskort. ${ }^{27-30 *}$ Svörun við píamíngjöf getur verið verri ef magnesíumskortur er einnig til staðar. ${ }^{31-33}$ Pví getur verið nauðsynlegt að leiðrétta magnesíumskort samfara píamíngjöf hjá sjúklingum með Wernicke.

раð eru margar ástæður fyrir hærri tíðni Wernicke við langvinna áfengissýki. Næringarskortur með minnkaðri inntöku píamíns, uppköst eða niðurgangur eru algeng í langvinnri áfengissýki. ${ }^{34}$ Við vannæringu skerðist geta meltingarvegar til að frásoga tiltekinn skammt píamíns. Раð lagast fyrst að fullu eftir sex til átta vikur á næringarríku fæði. ${ }^{35-37}$ Stór hluti píamínbirgða líkamans eru í lifrinni og geymslugeta hennar skerðist við lifrarsjúkdóma. ${ }^{34,37,}$ 38 Áfengisfráhvarf, tituróráð (delerium tremens) og sýkingar auka efnaskiptahraða og pörf fyrir píamín. ${ }^{1,25}$ Myndun starfhæfra ensíma (TK, PDH og $\alpha-\mathrm{KGDH})$ er tregari í áfengissjúkum vegna verri nýtingar píamíns (lægra hlutfall er á virku formi (TDP) og magnesíumskortur er algengur). Langvarandi áfengisdrykkja veldur fjölgun (upregulation) á NMDA-viðtökum sem virðist auka taugaskaða við píamínskort fyrir tilstilli NMDAviðtaka miðlaðs frumuskaða..$^{28,29,39}$

\section{Meinavefjabreytingar i heila}

Vefjabreytingum við Wernicke má skipta í bráðar breytingar og langvarandi eða varanlegar breytingar.

Bráðar breytingar sjást fyrst og fremst í vörtukjörnum (corpora mammillaria), umhverfis priðja og fjórða heilahólf og smugu. Pær eru mest einkennandi og sjúkdómsgreinandi fyrir Wernicke. ${ }^{110}$ Smáblæðingar í vörtukjörnum (10\%) eða umhverfis priðja heilahólf geta sést með berum augum en útlit heilans er eðlilegt í um $30 \%$ tilfella (mynd 1a-1c). ${ }^{1,}{ }^{10}$ Smásjárskoðun er nauðsynleg til sjúkdómsgreiningar og sýnir nær undantekningarlaust vefjabreytingar í vörtukjörnum og langoftast víðar í undirstúku (hypothalamus), stúku (thalamus), einkum í bak- og miðlægum kjörnum (nuclei dorsomediales), umhverfis smugu (periaqueductal gray matter) í augnhreyfikjörnum (nuclei nn. oculomotorii), baklægum kjarna skreyjutaugar (nucleus dorsalis $n$. vagi), í andarkjörnum (nuclei vestibulares), í kjarna fráfærandataugar (nucleus nervi abducentis) og víðar. 110, 40 Smásæju breytingarnar á bráðastiginu taka fyrst og fremst til æða og taugalóar (neuropil). Eru pær óeðlilega áberandi háræðar vegna stækkunar pelfrumna (endothelial cells) og hugsanlega háræðanýmyndunar, bjúgs, blóðkornaleka og smáblæðinga umhverfis pær. Stjarnfrumuviðbrögð (astrocytic reaction) verða fljótlega áberandi og skemmd á mýli og taugasímum (axons) en fækkun taugafrumna er oft ekki áberandi í vörtukjörnum (mynd 1d-1f). ${ }^{1-3,7,10,41}$

Varanlegar (langvarandi) breytingar einkennast af eyðingu taugavefjar á fyrrnefndum svæðum og taugatróðsmyndun (gliosis) í hans stað. Мeð berum augum geta sést rýrir vörtukjarnar og víkkuð priðja og fjórða heilahólf og smuga. Við smásjárskoðun sést fjölgun stjarnfrumna, eyðing á taugavef og útbreidd taugatróðsmyndun í 
vefnum. Hins vegar hefur pel háræða eðlilegt útlit

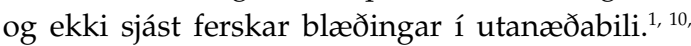
40, 41 Varanlegu breytingarnar hafa takmarkaðri útbreiðslu en pær bráðu og eru oftast bundnar við vörtukjarna og bak- og miðlæga kjarna stúku. ${ }^{42}$

Hjá einstaklingum með meinavefjabreytingar Wernicke í heila er jafnframt algengt að finna hrörnun í fremri- og efri hluta hnykilorms (vermis cerebelli). Slík hrörnun sést hjá rúmlega priðjungi tilfella með berum augum og nær helmingi við smásjárskoðun (mynd 2). ${ }^{1,10}$

\section{Sjúkdómseinkenni}

Klínísk einkenni Wernicke (tafla I) koma fram með bráðum hætti eða á örfáum dögum. Megineinkennin eru: 1) breytingar á hugarástandi (mental status) eða ruglástand, 2) truflun á augnhreyfingum, 3) óstöðugt göngulag eða stöðu- og göngulagstruflun (stance and gait ataxia). Vanalega sjást eitt eða tvö af megineinkennum við skoðun og öll prjú sjást aðeins hjá priðjungi sjúklinga. ${ }^{1}$

Breyting á hugarástandi: Algengast er almennt ruglástand með preytu og sinnuleysi, oft án áberandi óróleika. Athygli, einbeiting og minni eru skert. Í alvarlegri tilfellum getur sést tituróráð, meðvitundarskerðing eða meðvitundarleysi. ${ }^{1}$

Truflun á augnhreyfingum: Lárétt augnatin (horizontal nystagmus) er algengast og margir eru líka með lóðrétt augnatin (vertical nystagmus). Oft sést veiklun á hliðlæga réttivöðva augnhnattar (m. rectus lateralis bulbi oculi) eða ósamhæfð augnstaða (dysconjugate gaze). Önnur sjaldgæfari augneinkenni geta sést: Misvíð sjáöldur, minnkuð ljóssvörun, blæðingar í sjónhimnu, sig á efra augnloki (ptosis), sjónsviðsskerðing eða bjúgur í sjóntaug (optic disc). ${ }^{1}$ I alvarlegum veikindum getur sést algjör lömun augnhreyfinga og ekki er hægt að framkalla augnhreyfingar með pví að snúa höfðinu (doll's eyes) eða með pví að dæla ísvatni í eyru. Pá getur sést lækkaður líkamshiti og lágprýstingur. ${ }^{43}$

Óstöðugt göngulag sést hjá langflestum í mismiklum mæli. Slíkt getur verið allt frá vægu óöryggi við gang með erfiðleikum við að ganga eftir beinni línu (tandem, heel-to-toe walking) til göngulags sem er breiðspora og mjög óöruggt. Í alvarlegustu tilfellum getur sjúklingur hvorki setið uppi, staðið né gengið prátt fyrir mikla hjálp. ${ }^{1}$

Í bráðum veikindum getur sést stjórnleysi eða óregluhreyfingar (ataxia) á útlimum, oftast við hælhné próf. Sjaldnast er sjúklingur pvoglumæltur (ataxic speech). ${ }^{1}$ Jafnvægisleysi við að sitja, standa og ganga í bráðum Wernicke er talið vera vegna alvarlegrar vanstarfsemi í andarkjörnum. Tvær
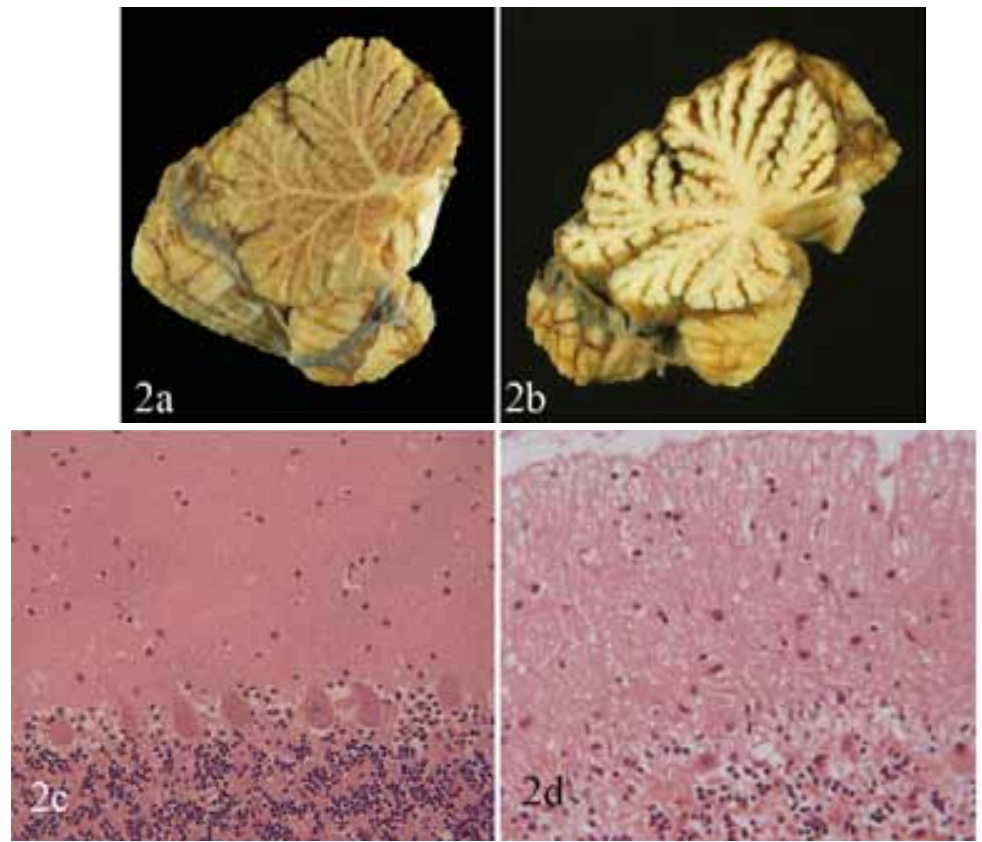

Mynd 2. Eðlilegur hnykilormur (2a). Veruleg rýrnun hnykilorms (2b). Eðlilegur hnykilbörkur (ljóssmásjá, HE, 2c). Rýrnun og pynning hnykilbarkar. Purkinje-frumur eru að mestu horfnar, mikil fækkun kornfrumna (granular cells) en fjölgun taugatróðsfrumna $i$ baunalagi (stratum moleculare) (2d).

Tafla I. Klínísk einkenni Wernicke-sjúkdóms.

\begin{tabular}{|c|c|}
\hline $\begin{array}{l}\text { Sjúkdómseinkenni eða } \\
\text { teikn }\end{array}$ & Nánari lýsing \\
\hline Breyting á hugarástandi & $\begin{array}{l}\text { Almennt ruglástand. } \\
\text { Skerðing á meðvitund, stundum meðvitundarleysi. } \\
\text { Tituróráð (delerium tremens). }\end{array}$ \\
\hline Truflun á augnhreyfingum & $\begin{array}{l}\text { Lárétt eða lóðrétt augnatin (horizontal/vertical nystagmus). } \\
\text { Veiklun eða lömun á hliðlæga réttivöðva augnhnattar (lateral } \\
\text { rectus palsy, n. abducens). } \\
\text { Ósamstæð augnstaða (dysconjugate gaze). } \\
\text { Sjaldgæfari teikn: Misvíð sjáöldur, minnkuð ljóssvörun, } \\
\text { blæðingar í sjónhimnu, sig á efra augnloki (ptosis), } \\
\text { sjónsviðsskerðing eða bjúgur í sjóntaugardiski. }\end{array}$ \\
\hline $\begin{array}{l}\text { Stöðu- og } \\
\text { göngulagstruflun }\end{array}$ & $\begin{array}{l}\text { Væg: Óeðlilega erfitt að ganga eftir beinni línu (tandem walk). } \\
\text { Meðalslæm: Gengur breiðspora og óöruggt án hjálpar. } \\
\text { Slæm: Getur aðeins gengið og staðið með hjálp. } \\
\text { Sjaldgæfari teikn: Stjórnleysi í fótum eða höndum og } \\
\text { pvoglumælgi (ataxic speech). }\end{array}$ \\
\hline Fjöltaugamein & $\begin{array}{l}\text { Brátt úttaugamein getur verið fyrirboði Wernicke. } \\
\text { Minnkuð eða horfin sinaviðbrögð. Minnkaður vöðvakraftur. } \\
\text { Verkir eða minnkað skyn, byrjar í tám, skríður upp fætur og } \\
\text { síðan fingur og hendur. }\end{array}$ \\
\hline $\begin{array}{l}\text { Önnur eða sjaldgæfari } \\
\text { teikn }\end{array}$ & $\begin{array}{l}\text { Andlitslömun beggja vegna. } \\
\text { Mænukylfulömun (bulbar paralysis): Kyngingarerfiðleikar, } \\
\text { pvoglumælgi. } \\
\text { Raddbreyting (hás eða veik rödd). } \\
\text { Lágur líkamshiti. } \\
\text { Stöðubundinn lágprýstingur. } \\
\text { Pvagtregða. }\end{array}$ \\
\hline
\end{tabular}

rannsóknir hafa sýnt að slík vanstarfsemi í peim er nær undantekningarlaust til staðar í Wernicke. Slíkt má staðfesta með pví að sprauta ísvatni í hlustir eða með svipuðum prófum á „,vestibuloocular" svörun. Í Wernicke sést skert eða engin 
Tafla II. Greiningarskilmerki líklegs Wernicke-sjúkdóms. Allir sjúklingar með líklegan Wernicke ættu að fá tafarlausa meðferð með stórum skömmtum af piamíni.

Greining líklegs Wernicke-sjúkdóms meðal áfengissjúkra krefst bæði 1) og 2):

1) Saga eða teikn um langvinna áfengissýki.

2) Eitthvert eitt eftirtalinna óútskýrðra einkenna:

- Brátt ruglástand (ekki vegna ölvunar) eða tituróráo (delerium tremens).

- Skert meðvitund.

- Minnistruflun.

- Augnvöðvalömun eða augnatin (nystagmus).

- Stjórnleysi í útlimum (ataxia, ekki vegna ölvunar) (*).

- Oútskýrð lækkun á líkamshita ásamt lækkun á blóðprýstingi.

(*) Pess má geta að stjórnleysi (ataxia) í Wernicke einkennist af óstöđugleika eđa óregluhreyfingum sjúklings er hann situr uppi, stendur eða gengur. Pað er talið orsakast af bráđri vanstarfsemi beggia vegna í andarkjörnum (hægt er að meta slíkt með kalórísku prófi á starfsemi peirra), oft með litlum eða engum óregluhreyfingum í útlimum viơ hæl-hné eða fingur-nef próf. svörun pegar ísvatni er sprautað í hlustir. Í kjölfar píamínmeðferðar líða allt að tveir mánuðir par til svörunin verður eðlileg að nýju. ${ }^{44,45}$ Hins vegar er talið að langvinn göngulagstruflun sem getur sést eftir að bráðum Wernicke lýkur (og er oft einnig til staðar hjá áfengissjúkum án fyrri Wernicke) orsakist af hrörnun í hnykilormi (sé pví ekki tengd starfsemi andarkjarna).

Fjöltaugamein (polyneuropathy) finnst hjá 60-82\% einstaklinga með Wernicke og getur sést í neðri útlimum (57\%) eða bæði neðri og efri útlimum (25\%). ${ }^{1,46}$ Brátt fjöltaugamein er algengur undanfari sjúkdómsins. ${ }^{4,}{ }^{47}$ Korsakoff lýsti pví pannig að hjá meirihluta sjúklinganna hefðu veikindin hafist með fjöltaugameini (,psychosis polyneuritica“). ${ }^{4}$ Úttaugameinið einkennist af minnkuðum eða horfnum sinaviðbrögðum, minnkuðu skyni og vöðvakrafti eða verkjum. Skyntruflanir og máttleysi byrjar í tám, skríður upp fæutur og síðan frá fingrum upp hendur. ${ }^{1}$

Taugamein í sjálfráða taugakerfinu er sjaldgæfara við Wernicke. Рað getur komið fram 1 semjuhluta (sympathetic) sjálfráða taugakerfisins með stöðubundnum lágprýstingi eða hjásemjuhluta (parasympathetic) pess með pvagtregðu. Einnig geta breytingar í skreyjutauginni ( $n$. vagus) valdið kyngingarerfiðleikum eða raddbreytingu en pá verður röddin veik eða hás. ${ }^{48}$

Sjaldgæfari einkenni og teikn: Lágur líkamshiti sést sjaldan (1-4\%) og er talinn stafa af skemmd í afturhluta undirstúku. 1, 10, 49 Lágprýstingur sést hjá 2\% tilfella. Sjaldgæft er að sjá andlits-, mænukylfulömun (bulbar paralysis) ${ }^{1}$ eða lömun í útlimum með auknum sinaviðbrögðum og Babinskisvörun. ${ }^{50}$

\section{Skað̃i í kjölfar Wernicke-sjúkdóms}

Ef einstaklingur með bráðan Wernicke fær ekki píamín með fæðu eða öðru móti deyr hann. Jafnvel pó hann sé meðhöndlaður er algengt að hann nái sér ekki að fullu. ${ }^{1}$ Korsakoffminnistruflun getur orðið í kjölfar bráðs Wernicke. Pá man einstaklingurinn ekki atburði sem gerðust á tilteknu tímabili fyrir veikindin (afturvirk minnistruflun) né pað sem gerist eftir pau (framvirk minnistruflun). Sjúklingar með Korsakoff-minnistruflun eru með skert minni (episodic memory) og geta illa eða ekki lært eða munað nýja hluti eða atburði í kjölfar bráðra veikinda. Peir hafa lítið innsæi í fötlun sína og eru frumkvæðisminni og jafnvel skeytingarlausir um nánasta umhverfi sitt. ${ }^{1,4}$ Í stærstu rannsókninni til pessa á bráðameðferð og skaða Wernicke var sjúklingum gefinn mun minni skammtur af píamíni (50-100 mg daglega) en nýlega hefur verið ráðlagt (600-1500 mg daglega). Horfur voru mjög slæmar pví $24 \%$ sjúklinga létust og $81 \%$ peirra sem lifðu af fengu Korsakoff-minnistruflun. ${ }^{1}$ Á fyrstu mánuðunum varð einhver bati á minnistrufluninni hjá flestum. Hann gat verið fullkominn $(21 \%)$, umtalsverður (25\%), vægur (28\%) eða enginn (26\%). ${ }^{1}$ Flestir fengu langvarandi göngulagstruflun (62\%) í kjölfar bráđs Wernicke. Einkenndist hún af hægu, breiðspora göngulagi eða skertri getu til að ganga línugang. ${ }^{1}$ I kjölfar píamíngjafar gengu augnvöðvalamanir hins vegar mjög hratt til baka, oftast sást bati innan nokkurra klukkustunda. Augnatin var lengur að lagast og í $60 \%$ tilfella hvarf pað aldrei að fullu. ${ }^{1}$

\section{Greining}

Bráður Wernicke-sjúkdómur er mjög vangreindur. Rannsókn sýndi að einungis 20\% tilfella greindust klínískt fyrir andlátið, jafnvel pótt flestir hafi verið skoðaðir af lækni á sjúkrahúsi skömmu áður. ${ }^{51}$ I klínískum rannsóknum er einungis priðjungur sjúklinga með öll prjú meginteikn til staðar ${ }^{1}$ og í afturskyggnum rannsóknum á meinafræðilega greindum tilfellum eru einungis $16 \%$ tilfella með öll prjú meginteiknin skráð í sjúkraskýrslu. ${ }^{51}$ Hugsanlega er taugaskoðun áfengissjúkra með Wernicke ábótavant. Pannig greina sjúkraskýrslur oftast frá breyttu hugarástandi en sjaldnar frá einkennum sem krefjast taugaskoðunar, eins og truflun á augnhreyfingum, óregluhreyfingum eða göngulagstruflunum..$^{5,6,11,51}$

Nauðsynlegt er fyrir lækna að pekkja vel einkenni sjúkdómsins og hugleiða greininguna hjá áfengissjúkum sem eru í bráđu ruglástandi eða með göngulagstruflun, taugaskoða sjúklinga til að greina sértækari einkenni og hafa í huga аð einungis minnihluti sjúklinga með Wernicke er með öll prjú meginteikn sjúkdómsins við skoðun. Einnig er mikilvægt að hafa hugfast að mörg einkennanna geta líkst ölvunaráhrifum 
áfengis eða lyfja, áhrifum sýkingar, brenglunar á blóðsöltum og svo framvegis.

Taugaskoðun og mat: Leggja parf mat á hugarástand sjúklings: vökustig, áttun og hvort til staðar sé ruglástand. Einnig parf að athuga hvort til staðar sé augnvöðvalömun eða augnatin og hvort sjúklingurinn getur setið uppi í rúmi, staðið og gengið eðlilega án hjálpar, par með talið línugang. Eftir skoðun er rétt að velja rannsóknir á sjúklingi með líklegar mismunagreiningar og fylgikvilla 1 huga. Pannig á við minnsta tilefni á að fá bráða tölvusneiðmynd af heila og segulómrannsókn með skuggaefni ætti að taka brátt eða fljótlega. Einnig ætti að mæla magnesíumstyrk í sermi.

Greining líklegs Wernicke: Gagnlegar leiðbeiningar um greiningu og meðhöndlun á slysaog bráđamóttökum voru gefnar út árið 2001 af Bresku læknasamtökunum (Royal College of Physicians). ${ }^{52}$ Mikilvæg viðbót við pær leiðbeiningar eru ráđleggingar frá Thomson og Marshall um meðferð sjúklinga utan sjúkrahúsa sem eru í hættu á að fá Wernicke. ${ }^{53}$ Samkvæmt peim parf einstaklingur einungis að vera með líklegan Wernicke eða vera talinn vera með sjúkdóminn til að fá tafarlausa meðhöndlun með stórum skömmtum af píamíni. Einstaklingar sem eru með vísbendingar um langvinna áfengissýki eru líklega með sjúkdóminn ef til staðar er eitthvert eftirtalinna einkenna sem ekki er hægt að skýra með öðru móti: Brátt ruglástand (ekki vegna ölvunar), tituróráð, minnistruflun, skert meðvitund, augnvöðvalömun eða augnatin, stjórnleysi (ekki vegna ölvunar) eða óútskýrð lækkun á líkamshita ásamt lækkuðum blóðprýstingi (tafla II). ${ }^{52,53}$ Pess má geta að stjórnleysi sjúklings með Wernicke einkennist af óstöðugleika eða óregluhreyfingum sjúklings er hann situr uppi, stendur eða gengur. Раð er talið orsakast af bráðri vanstarfsemi beggja vegna í andarkjörnum, oft með litlum eða engum óregluhreyfingum í útlimum við hæl-hné eða fingur-nef próf. ${ }^{1}$

Greiningarskilmerki fyrir Wernicke og Korsakoff hjá áfengissjúklingum birtust 1997 (tafla III). Markmið peirra var að auka næmi klínískrar greiningar. Pau byggja á að tvö af fjórum skilmerkjum séu til staðar: 1) næringarskortur, 2) augnhreyfitruflun (eye signs), 3) klínísk truflun í starfsemi hnykils (cerebellar signs), 4) breyting á hugarástandi eða væg minniskerðing. Korsakoff-minnistruflun er greind ef sjúklingur uppfyllir greiningarskilmerki fyrir Wernicke og er auk pess með minnisleysi og óáttun án bráðs rugls. Sjúklingur hefur pá eðlilega skynjun og meðvitund og minnistruflun lagast ekki við meðferð píamíns. Greiningarskilmerkin voru sannreynd með afturskyggnri rannsókn á 106
Tafla III. Greiningarskilmerki Wernicke-sjúkdóms. Greining krefst tveggja af fjórum skilmerkjum.

\begin{tabular}{|c|c|}
\hline Skilmerki & Nánari lýsing \\
\hline Næringarskortur & $\begin{array}{l}\text { Saga um verulega skerta fæðuinntöku. } \\
\text { Líkamspyngdarstuðull (BMI) tveim staðalfrávikum undir eðlilegu } \\
\text { gildi. } \\
\text { Staðfestur píamínskortur samkvæmt mælingu í blóði. }\end{array}$ \\
\hline $\begin{array}{l}\text { Augnhreyfitruflun (eye } \\
\text { signs) }\end{array}$ & $\begin{array}{l}\text { Augnvöđvalömun. } \\
\text { Augnatin (nystagmus). } \\
\text { Ósamstæð augnstaða (gaze palsy). }\end{array}$ \\
\hline $\begin{array}{l}\text { Klínísk truflun í starfsemi } \\
\text { hnykils (cerebellar signs) }\end{array}$ & $\begin{array}{l}\text { Óstöđugleiki við̃ að̃ sitja, standa eða ganga (*). } \\
\text { Stjórnleysi útlima (ataxia) við hæl-hné próf, past pointing eða } \\
\text { dysdiadokokinesis. }\end{array}$ \\
\hline $\begin{array}{l}\text { Breyting á hugarástandi } \\
\text { eða } \\
\text { væg minnisskerðing }\end{array}$ & $\begin{array}{l}\text { Breyting á hugarástandi: } \\
\text { Ruglástand. } \\
\text { Óáttun í 2/3 (eigin persóna, staður eða stund). } \\
\text { Skert meðvitund eða meðvitundarleysi. } \\
\text { Skert geta við talnarunupróf (digit span test) } \\
\text { Væg minnisskerðing: } \\
\text { Getur ekki munað tvö eða fleiri orð i fjögurra atriða minnisprófi } \\
\text { (four item memory test). } \\
\text { Væg minnistruflun við taugasálfræððlega prófun. }\end{array}$ \\
\hline
\end{tabular}

(*) Pess má geta að ójafnvægi í bráđum Wernicke er líklega vegna bráđrar vanstarfsemi beggja vegna í andarkjörnum (hægt að̃ meta slíkt með kalórísku prófi á starfsemi peirra) en hér er pað flokkað undir truflun i starfsemi hnykils.

látnum áfengissjúklingum. Sjúkraskýrslur voru skoðaðar og bornar saman við niðurstöður krufninga. Næmið reyndist 85\% og sértæki 100\% fyrir greiningu Wernicke og fyrir greiningu Korsakoff var næmið $88 \%$. Hins vegar reyndist pað aðeins $50 \%$ við greiningu Wernicke ef einnig var til staðar lifrarheilakvilli. Líkleg skýring er að pað er mikil skörun á klínískum einkennum milli sjúklinga með heilakvilla vegna lifrarsjúkdóms og Wernicke. ${ }^{54}$ Greiningarskilmerkin hafa ekki verið sannreynd á framsæjan hátt og líklegt er að pau séu mjög ósértæk við greiningu bráðs Wernicke frá öðrum ástæðum heilakvilla (encephalopathy) meðal áfengissjúkra, sérstaklega hjá peim sem eru með langvinnan skaða í formi göngulagstruflunar eða augnatins eftir fyrri veikindi af sjúkdómnum. Hins vegar er ótvíræður kostur peirra fólginn í pví að flestir sem purfa á meðferð að halda fá hana og hljóta pví síður alvarlegan miðtaugakerfisskaða. Vafalaust fá margir ónauðsynlega stóran skammt af píamíni án pess að vera með Wernicke en meðferðin er ódýr og hefur afar sjaldan alvarlegar aukaverkanir.

Mæling á píamínskorti: Hægt er að sýna fram á píamínskort með mælingu á virkni transketólasa (TK) í rauðkornarofnu (hemolysed) blóði. Við píamínskort er virkni TK verulega minnkuð og eykst óeðlilega mikið (>25\%) pegar ofgnótt af TDP er bætt út í heilblóðið (aukin TDP áhrif). ${ }^{55,56}$ Einnig er hægt að mæla styrk píamíns, píamínfosfats og TDP í blóði eða rauðum blóðkornum á beinan hátt með litskiljunaraðferð (chromatography). ${ }^{57}$ Pessar 
Tafla IV. Staðfesting á líklegum Wernicke-sjúkdómi. Dæmigerð sjúkdómspróun, breytingar á segulómun eða niðurstöður krufningar geta staðfest klíníska greiningu. Mikilvægt er að meðhöndla án tafar alla sjúklinga með líklegan Wernicke með stórum skömmtum af píamíni, ekki skal bíða staðfestingar á greiningu áður en meðferð er hafin.

\section{Pættir sem staðfesta greiningu \\ Dæmigerðar breytingar á segulómun í \\ bráđum Wernicke-sjúkdómi}

Dæmigerður bati á augnvöðvalömun

eða augnatini í kjölfar píamínmeðferðar veikinda

Dæmigerðar hrörnunarbreytingar sjást við segulómrannsókn í kjölfar Wernicke

Sjúkdómsgreinandi meinvefjabreytinga

\section{Nánari lýsing}

Dæmigerðar samhverfar segulskinsbreytingar umhverfis priðja heilahólfið, í vörtukjörnum, miðlægum stúkum (medial thalami) og umhverfis smugu.

Fullkominn bati á augnvöðvalömun sést vanalega innan 10 daga. Bati á augnatini getur tekið allt að 12 vikur og hjá hluta sjúklinga hverfur pað aldrei að fullu.

\section{Nýtilkomin (eða versnun) prálát framvirk} minnistruflun (Korsakoff-minnistruflun), göngulagstruflun eða augnatin í kjölfar líklegs bráðs Wernicke-sjúkdóms.

Nokkrum vikum til mánuðum eftir bráđan Wernicke getur segulómun sýnt marktækt minnkaða vörtukjarna, nýtilkomna hrörnun á hnykilormi eða greinilega víkkun á priðja heilahólfi eða smugu.

Krufning á heila getur sýnt bráđar eđa langvinnar/varanlegar vefjabreytingar sem eru sjúkdómsgreinandi.
*Til að̃ meta minnkun á vörtukjörnum er hægt að mæla rúmmál peirra á segulómmyndum.

pað̃ er áætlað̃ samkvæmt

jöfnunni: $V \frac{4}{3}\left(a^{2} b\right)$ par sem $a$

er stysti og b lengsti radíus vörtukjarna. Eðlileg samanlögð stærð vörtukjarna hjá fullorðnum er $63,5 \pm 17,6 \mathrm{~mm}^{3}$ en í kjölfar WS verður langoftast umtalsverð minnkun á peim eđa: $24,3 \pm 11,1$ $\mathrm{mm}^{3}, 21,3 \pm 5,8 \mathrm{~mm}^{3}$ og $20,7 \pm$

$14,8 \mathrm{~mm}^{3}$, samkvæmt premur rannsóknum. Hins vegar er ekki marktæk minnkun við krufningu á vörtukjörnum hjá einstaklingum með langvinna áfengissýki sem ekki hafa fengið Wernicke. Að lokum eru vörtukjarnar minni en $23 \mathrm{~mm}^{3}$ hjá $64,5 \%$ einstaklinga i kjölfar Wernicke, 2,3\% áfengissjúkra án Wernicke og einungis $1,2 \%$ við̌miða.

Mynd 3. FLAIR myndir $i$ axial og sagittal plani sýna teikn um Wernickesjúkdóm. Aukið segulskin sést umhverfis III. heilahólf og miðlægt ístúku báðum megin (breið ör) ásamt auknu segulskini umhverfis smugu (grönn

ör). Einnig sést aukið

segulskin í súðarpynnu

(lamina tectalis) $(<)$ og smár vörtukjarni $(>)$ mælingar hafa pó takmarkað gildi við greiningu og eru ekki framkvæmdar á Íslandi.

Segulómrannsókn af heila: Greining Wernicke er klínísk og byggir á dæmigerðri sögu, skoðun og svörun við píamíngjöf ásamt einkennandi sjúkdómsgangi. Segulómun er mjög mikilvæg við greininguna, einkum ef erfitt er að koma við fullnægjandi taugaskoðun eða ef sjúkdómsmyndin er ódæmigerð. Segulómun getur einnig sýnt aðrar ástæður sem skýra einkenni sjúklings.

Dæmigerðar segulómbreytingar í bráðum Wernicke eru samhverfar segulskinsbreytingar (aukning í segulskini á T2 og minnkað segulskin á T1) umhverfis priðja heilahólfið, í vörtukjörnum, miðlægum stúkum og umhverfis smugu (sömu staðir og taugameinafræðilegar skemmdir). ${ }^{50}$ 58, 59 Breytingar á fyrrgreindum svæðum geta einnig sést á FLAIR myndröðum eða diffusion myndröðum (Diffusion-weighted imaging) (myndir 3-4).59, 60 Skuggaefnisupphleðsla sést í 63-67\% tilfella sem eru með breytingar sem benda til Wernicke. Hún er oftast bundin vörtukjörnum og er stundum eina sjáanlega breytingin við segulómrannsókn. ${ }^{50,59}$ Tvær rannsóknir á notkun segulómunar við greiningu bráðs Wernicke hafa lýst næmi sem er 53-58\% og sértæki $93 \%{ }^{61}$, 62 Pannig er algengt að seglómun sé eðlileg við bráðan Wernicke og pví útilokar eðlileg segulómun ekki sjúkdóminn.

Pegar frá líður (vikur til mánuðir) sýnir segulómun oft hrörnunarbreytingar í heila í kjölfar sjúkdómsins (minnkun á vörtukjörnum, stækkun á priðja heilahólfi, víkkun á smugu og jafnvel hrörnun á hnykilormi) (mynd 5). ${ }^{63}$ Tilkoma slíkra breytinga á segulómun í kjölfar bráora veikinda styður sterklega eða staðfestir klíníska greiningu. ${ }^{64-68 *}$

Staðfesting á líklegum Wernicke: Svörun við píamíngjöf, sjúkdómspróun og mögulegur skaði í kjölfar bráðra veikinda eru mjög einkennandi eða sértæk við sjúkdóminn og slíka klíníska pætti má nota ásamt mögulegum breytingum á segulómun til að staðfesta greiningu líklegs Wernicke (tafla IV).

\section{Mismunagreiningar}

Ölvunaráhrif áfengis og lyfja geta valdið öllum megineinkennum sjúkdómsins. Auk pess geta aðrir sjúkdómar líkst honum, bæði klínískt og við myndgreiningu og eru pessir helstir: 1) Drep í miðlægum hluta stúku beggja vegna (bilateral paramedian thalamic infarct) líkist klínískt bráðum Wernicke, ${ }^{69-71}$ 2) Drep í fremri hluta stúku eða í vörtustúkubraut (tractus mammillothalamicus) getur líkst klínískt Korsakoff, ${ }^{69,72,73}$ 3) Heilabólga af völdum cýtómegalóveiru (CMV) getur valdið
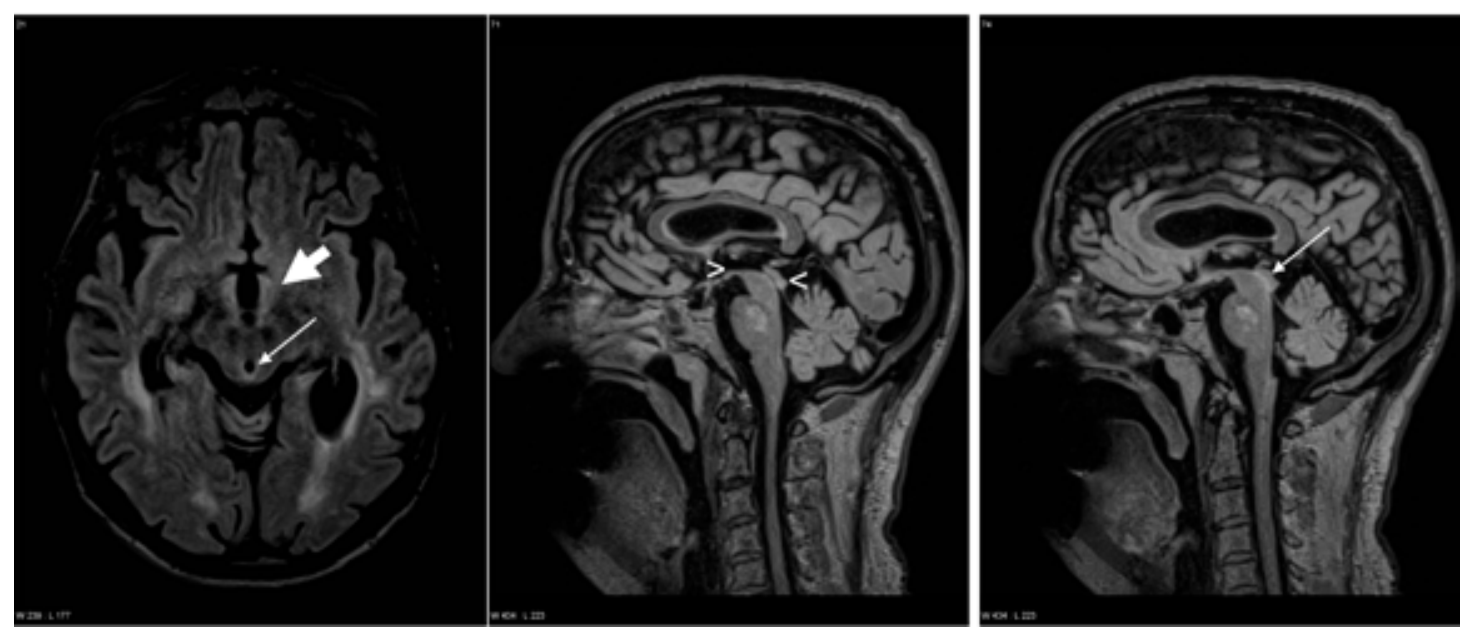
sömu sjúkdómseinkennum og breytingum við myndgreiningu og Wernicke og er pekkt í alnæmi, ${ }^{74,}{ }^{75}$ 4) Afmýlandi sjúkdómar, Behçetssjúkdómur í miðtaugakerfi og heilabólga vegna herpes simplex veiru (HSV) parf að hafa í huga í mismunagreiningu, 5) Heilakvilla vegna lifrarsjúkdóms (hepatic encephalopathy) getur verið mjög erfitt að greina klínískt frá bráđum Wernicke. ${ }^{54}$ Slíkt er sérlega erfitt hjá áfengissjúkum sem hafa áður fengið sjúkdóminn eða áfengistengda hrörnun í hnykli (alcoholic cerebellar degeneration) og hafa ætíð óstöðugt göngulag eða augnatin.

\section{Bráðameðferð við líklegum Wernicke}

Meðhöndla á alla áfengissjúka einstaklinga sem eru líklega með bráðan Wernicke. Pannig á að meðhöndla alla sem eru taldir hafa bráðan Wernicke (tafla II og III), hafa alvarlegan höfuðáverka eða aðrar ástæður sem torvelda taugaskoðun pannig að ekki er hægt að útiloka Wernicke með vissu. ${ }^{52}$ Einnig ættu læknar að vera vakandi fyrir sjúkdómnum hjá áfengissjúklingum með heilakvilla vegna lifrarsjúkdóms, jafnvel að meðhöndla pá með píamíni og meta klíníska svörun. ${ }^{54}$ Aldrei ætti að gefa píamín um munn sem meðferð við Wernicke eða sem fyrirbyggjandi meðferð pví frásog píamíns úr meltingarvegi er lítið og óáreiðanlegt hjá áfengissjúkum. Einungis á að gefa meðferð í bláæð eða vöðva. ${ }^{36,52,76}$

Ráðlögð meðferð píamíns: Ekki eru til samanburðarrannsóknir eða aðrar áreiðanlegar rannsóknir sem ákvarðað hafa besta skammt píamíns við Wernicke til að lágmarka skaða.77 Nýlegar leiðbeiningar varðandi viðeigandi skammt píamíns byggja á nokkrum páttum sem allir styðja mun stærri skammt af píamíni en áður tíðkaðist að gefa: 1) pekkingu á slæmum horfum sjúklinga við gjöf minni skammta af píamíni
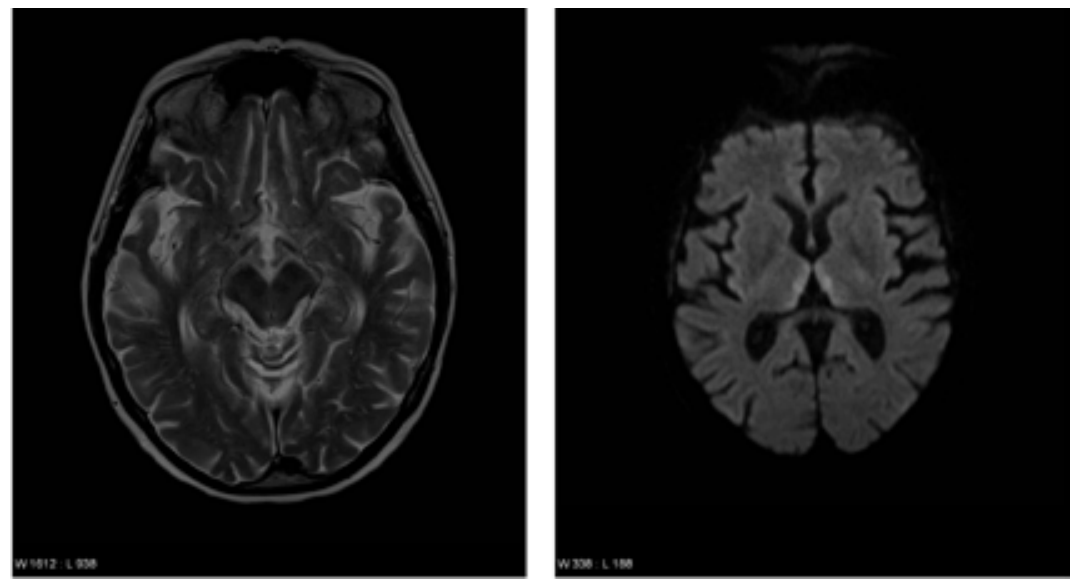

Mynd 4. T2 mynd sýnir hlutfallslega smáa vörtukjarna (mynd A). Diffusion mynd (DWI) sýnir minni diffusion sem segulskært svæði miðlægt og aftan til i thalamus bádum megin (mynd B). Sjúkdómsgreining snemma í sjúkdómsferli Wernicke er nauðsynleg til að koma í veg fyrir varanlegan heilaskaða. DWI er næmasta aðferðin til að sýna aukinn bjúg i frumu. Með DWI má lækkka greiningarpröskuld fyrir Wernicke og og DWI myndröðin er pví mikilvæg við mat á sjúklingum sem eru taldir vera með sjúkdóminn.

(50-100 mg daglega) sem áður tíðkuðust, 2) betri pekkingu á lyfjahvörfum píamíns í einstaklingum með píamínskort, 3) mismun í lyfjahvörfum píamíns milli áfengissjúkra og annarra, 4) birtum tilfellum og klínískri reynslu (einnig okkar reynslu af íslenskum tilfellum sem stendur til að birta) sem benda til minni eftirkasta við notkun stærri skammta af píamíni og 5) lágri tíoni alvarlegra aukaverkana við píamínmeðferð en bráðaofnæmi er afar fátíð aukaverkun við gjöf píamíns í vöðva eða bláæð. $35,39,52,78-81$

Nýlega hafa verið birtar tvennar leiðbeiningar um meðferð píamíns við Wernicke. Í öðrum peirra er ráðlagt að gefa píamín hýdróklóríð 500 mg prisvar á dag í prjá daga í bláæð. Ef jákvæð svörun sést er skammtur minnkaður í 500 mg einu sinni á dag í fimm daga til viðbótar, gefið í bláæð eða vöðva. Ef engin svörun sést er frekari meðferð stöðvuð eftir fyrstu prjá dagana og annarra skýringa leitað á einkennum sjúklings. ${ }^{52}$ Í hinum er ráðlagt að gefa píamínhýdróklóríð 200 mg

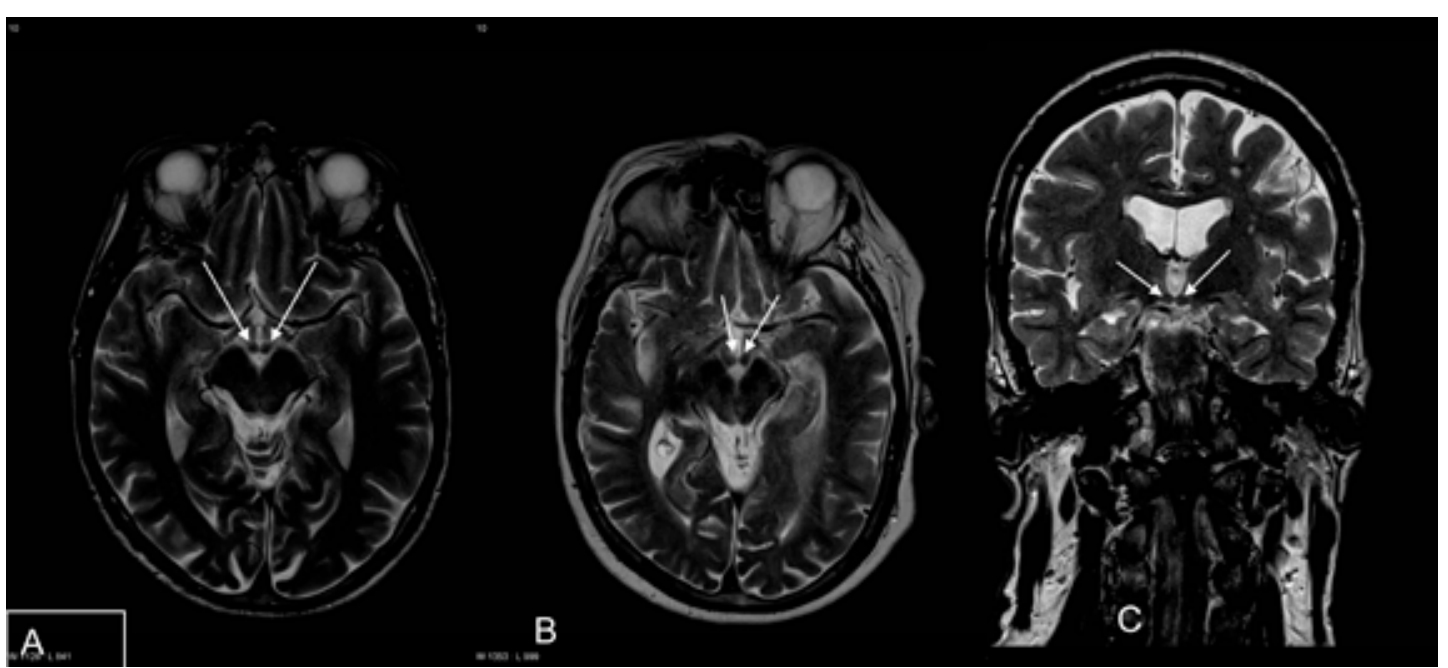

Mynd 5. Breytingar á vörtukjörnum í WernickeKorsakoff-sjúkdómi. Vörtukjarnar sjást jafnan best á T2 myndum (mynd A). Í brádum Wernickesjúkdómi getur sést skuggaefnisupphleðsla vörtukjörnum á T1 myndum (ekki sýnt á mynd). Hjá sjúklingum með Wernicke sjúkdóm (eða i kjölfar sjúkdómsins) geta sést hlutfallslega smáir vörtukjarnar (myndir B og C) samanborið við eðlilega vörtukjarna hjá heilbrigðum einstaklingi (mynd A). 
prisvar á dag í bláæð par til einkenni eru horfin. ${ }^{82}$ Hægt er að gefa píamín óblandað hægt í bláæð ${ }^{80,81}$ en báðar leiðbeiningar ráðleggja blöndun píamíns við $100 \mathrm{ml}$ af venjulegri saltvatnslausn eða 5\% glúkósalausn sem síðan er gefin sem dreypi í bláæð á 30 mínútum.

Leiðrétting á magnesíumskorti með magnesíumsúlfatdreypi í bláæð virðist skynsamlegt við bráðum Wernicke. Magnesíumskortur virðist auka skaða á taugakerfi við píamínskort ${ }^{27-30}$ og svörun við píamíngjöf getur verið verri ef verulegur magnesíumskortur er einnig til staðar. ${ }^{31-33}$ Frekari rannsóknir á hlutverki magnesíumskorts î Wernicke og skaða á taugakerfi við langvinna áfengissýki er spennandi möguleiki. Leiðrétting magnesíumskorts með magnesíum í inntöku á ekki við um sjúklinga með bráðan sjúkdóminn vegna hættu á skertu frásogi og nauðsyn á hraðri leiðréttingu. Pess má geta að pað tekur nokkra daga að leiðrétta magnesíumskort innan frumna með magnesíumdreypi. ${ }^{83,84}$

\section{Fyrirbyggjandi meðfero}

Pegar við innlögn á að gefa fyrirbyggjandi píamín öllum áfengissjúklingum sem eru í verulegri hættu að fá sjúkdóminn, par með öllum áfengissjúklingum sem purfa afeitrun með lyfjum, hafa merki um vannæringu eða purfa glúkósagjöf í æð. Almennt lystarleysi, ógleði og uppköst geta verið fyrstu teikn píamínskorts. ${ }^{85}$ Раð er algjörlega ófullnægjandi að gefa píamín um munn til að fyrirbyggja sjúkdóminn hjá áfengissjúkum sem leggjast inn á sjúkrahús. Peim ætti að gefa píamínhýdróklóríð, 200-250 mg á dag í prjá til fimm daga í vöðva, til að minnka hættu á sjúkdómnum. 53,79, 86

Ráðleggja ætti sjúklingum með virka langvinna áfengissýki að taka daglega vítamíntöflur sem innihalda að minnsta kosti $15 \mathrm{mg}$ af píamíni (sterkar B-kombíntöflur). Slík gjöf dregur úr líkum á píamínskorti hjá áfengissjúkum en píamínskortur veldur mörgum af peim langvinnu skemmdum á taugakerfi sem áfengissýki getur valdið. ${ }^{1,} 26$ Skynsamlegt er setja töflurnar í lyfjaskömmtun frá apóteki eða að nánir ættingjar sjái um innkaup peirra til að auka meðferðarheldni.

\section{Pakkir}

Pakkir fá læknarnir Andrés Magnússon, Ari Jóhannesson, Bjarni Össurarson, Kristinn Sigvaldason, Valgerður Rúnarsdóttir og Pórarinn Tyrfingsson fyrir gagnlegar ábendingar.

\section{Heimildir}

1. Victor M, Adams R, Collins G. The Wernicke-Korsakoff syndrome and related disorders due to alcoholism and malnutrition. 2 ed. F.A. Davis Company, Fíladelfíu 1989.

2. Wernicke C. Die acute, hämorrhagische Polioencephalitis superior. In: Lehrbuch der Gehirnkrankheiten fur Aerzte und Studirende, vol 2. Theodor Fischer, Berlin, Kassel 1881: 22942.

3. Thomson AD, Cook CCH, Guerrini I, Sheedy D, Harper C, Marshall EJ. Wernicke's encephalopathy revisited. Translation of the case history section of the original manuscript by Carl Wernicke ,Lehrbuch der Gehirnkrankheiten fur Aerzte and Studirende' (1881) with a commentary. Alcohol Alcohol 2008; 43: 174-9.

4. Victor M, Yakovlev PI. S.S. Korsakoff's psychic disorder in conjunction with peripheral neuritis; a translation of Korsakoff's original article with comments on the author and his contribution to clinical medicine. Neurology 1955; 5: 394406

5. Torvik A, Lindboe CF, Rogde S. Brain lesions in alcoholics. A neuropathological study with clinical correlations. J Neurol Sci 1982; 56: 233-48.

6. Lindboe CF, Loberg EM. Wernicke's encephalopathy in nonalcoholics. An autopsy study. J Neurol Sci 1989; 90: 125-9.

7. Cravioto H, Korein J, Silberman J. Wernicke's encephalopathy. A clinical and pathological study of 28 autopsied cases. Arch Neurol 1961; 4: 510-9.

8. Victor M, Laureno R. Neurologic complications of alcohol abuse: Epidemiologic aspects. In: Schoenberg BS, ed. Advances in Neurology, Vol 19. Raven Press, New York 1978: 603-17.

9. Harper C, Fornes P, Duyckaerts C, Lecomte D, Hauw JJ. An international perspective on the prevalence of the WernickeKorsakoff syndrome. Metab Brain Dis 1995; 10: 17-24.

10. Harper C. The incidence of Wernicke's encephalopathy in Australia--a neuropathological study of 131 cases. J Neurol, Neurosurg Psychiatr 1983; 46: 593-8

11. Lindboe CF, Loberg EM. The frequency of brain lesions in alcoholics. Comparison between the 5-year periods 19751979 and 1983-1987. J Neurol Sci 1988; 88: 107-13.

12. Doraiswamy PM, Massey EW, Enright K, et al. WernickeKorsakoff syndrome caused by psychogenic food refusal: MR findings. Am J Neuroradiol 1994; 15: 594-6.

13. Selitsky T, Chandra P, Schiavello HJ. Wernicke's encephalopathy with hyperemesis and ketoacidosis. Obstet Gynecol 2006; 107: 486-90.

14. Chiossi G, Neri I, Cavazzuti M, Basso G, Facchinetti F. Hyperemesis gravidarum complicated by Wernicke encephalopathy: background, case report, and review of the literature. Obstet Gynecol Surv 2006; 61: 255-68.

15. Singh S, Kumar A. Wernicke encephalopathy after obesity surgery: a systematic review. Neurology 2007; 68: 807-11.

16. Koguchi K, Nakatsuji Y, Abe K, Sakoda S. Wernicke's encephalopathy after glucose infusion. Neurology 2004; 62: 512.

17. Francini-Pesenti F, Brocadello F, Famengo S, Nardi M, Caregaro L. Wernicke's encephalopathy during parenteral nutrition. JPEN J Parenter Enteral Nutr 2007; 31: 69-71.

18. Jagadha V, Deck JH, Halliday WC, Smyth HS. Wernicke's encephalopathy in patients on peritoneal dialysis or hemodialysis. Ann Neurol 1987; 21: 78-84.

19. Barbara PG, Manuel B, Elisabetta M, et al. The suddenly speechless florist on chronic dialysis: the unexpected threats of a flower shop? Diagnosis: dialysis related Wernicke encephalopathy. Nephrol Dial Transplant 2006; 21: 223-5.

20. Boniol S, Boyd M, Koreth R, Burton GV. Wernicke encephalopathy complicating lymphoma therapy: case report and literature review. South Med J 2007; 100: 717-9.

21. Onishi H, Kawanishi C, Onose M, et al. Successful treatment of Wernicke encephalopathy in terminally ill cancer patients: report of 3 cases and review of the literature. Support Care Cancer 2004; 12: 604-8.

22. Bleggi-Torres LF, de Medeiros BC, Werner B, et al. Neuropathological findings after bone marrow transplantation: an autopsy study of 180 cases. Bone Marrow Transplant 2000; 25: 301-7.

23. Alcaide ML, Jayaweera D, Espinoza L, Kolber M. Wernicke's encephalopathy in AIDS: a preventable cause of fatal neurological deficit. Int J STD AIDS 2003; 14: 712-3.

24. Butterworth RF, Gaudreau C, Vincelette J, Bourgault AM, Lamothe F, Nutini AM. Thiamine deficiency and Wernicke's encephalopathy in AIDS. Metab Brain Dis 1991; 6: 207-12.

25. Butterworth RF. Thiamin. In: Shils ME, M S, C RA, B C, J CR, eds. Modern Nutrition in Health and Disease: Lippincott Williams \& Wilkins; 2005: 426-33. 